\title{
Race at Work: A Comparative History of Mining Labor and Empire on the Central African Copperbelt and the Fushun Coalfields,
} ca. 1907-1945*

\author{
Duncan Money \\ African Studies Centre Leiden International Studies Group, University of the Free State
}

Limin Teh

Institute for Area Studies, Leiden University

Corresponding author: Duncan Money, E-mail: d.j.money@asc.leidenuniv.nl

\section{Introduction}

In many ways, the vast industrial complexes that developed on the Central African Copperbelt and the Fushun coalfields in the early twentieth century were very different places. One on a high plateau stretched out across the border between what is now Democratic Republic of Congo and Zambia with a sub-tropical climate; the other on the rolling foothills of Changbai Mountains in what is now Liaoning Province, northeastern China, with a humid continental climate. Yet anyone who visited either of these places would immediately and unavoidably have become aware of a basic fact about both: that racial hierarchies governed life and work on the mines. This article is about that basic fact, and in it we aim to make a two-fold contribution: First, it is a comparative history of mining regions, which, although it might seem an area of study ripe for comparison, is seldom undertaken. Second, through this comparison to argue that the prevalence and significance of race as a way of organizing life and work in the mining industry has been underestimated. We support this claim with an overview of production and everyday life in two seemingly very different mining regions: the Fushun coalfields and the Central African Copperbelt (see figure 1).

Despite significant political, cultural, and geographical differences, the way that labor was organized on racial lines was remarkably similar. There were no direct connections between the two mining regions, or at least none that we have uncovered, yet the array and depth of similarities between the two are striking. The possibility that these similarities are coincidental is, we think, remote; instead, we believe they reveal

\footnotetext{
${ }^{*}$ We would like to thank Stefano Bellucci for suggesting and organizing the joint seminar where we realized the remarkable similarities between our case studies. We are also grateful for the helpful feedback provided by the journal's peer reviewers.

(c) International Labor and Working-Class History, Inc., 2022. This is an Open Access article, distributed under the terms of the Creative Commons Attribution licence (https://creativecommons.org/licenses/by/4.0/), which permits unrestricted re-use, distribution, and reproduction in any medium, provided the original work is properly cited.
} 


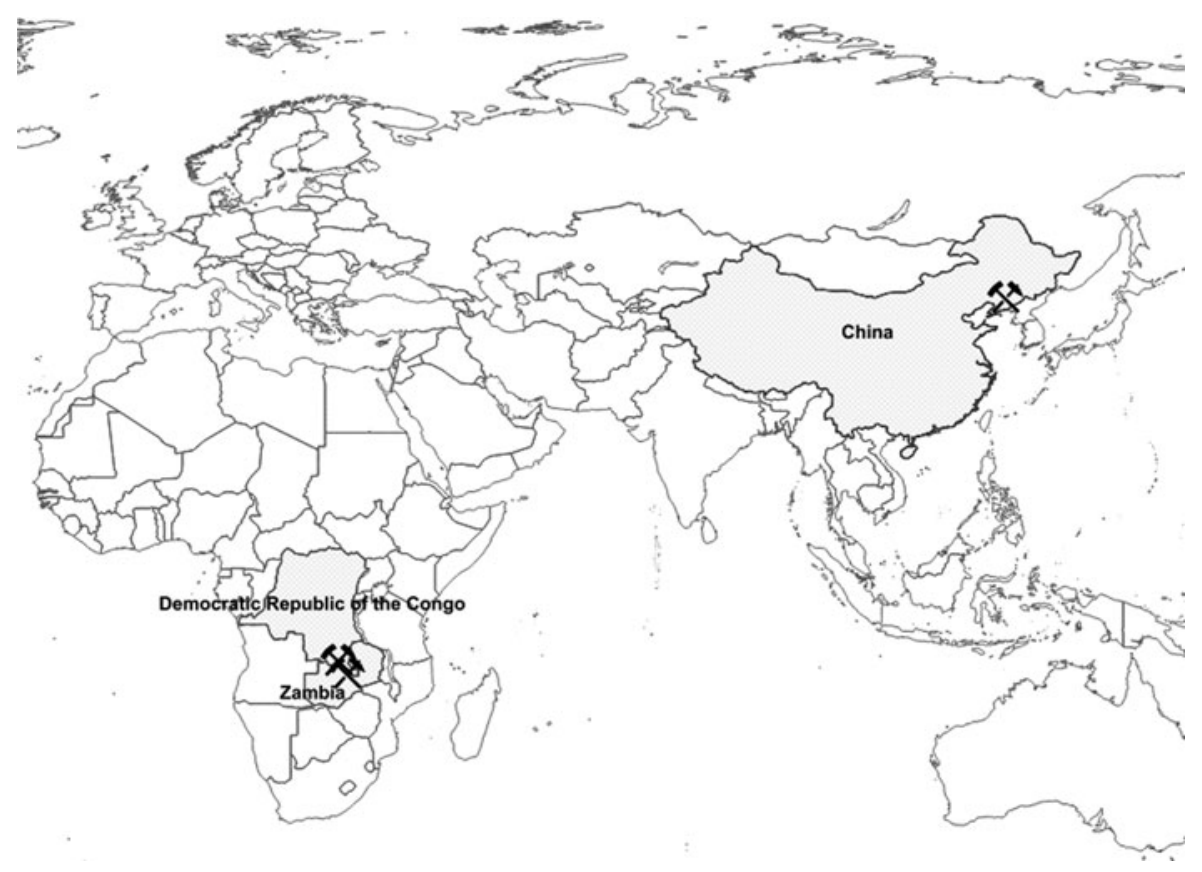

Figure 1. Map showing the Central African Copperbelt and Fushun coalfields

something fundamental about the organization of work and everyday life in the mining industry over the nineteenth and twentieth centuries, which has been underappreciated. Our realization about the salience of this comparison came about by chance, and this itself points to the utility of scholars reading widely outside their immediate area of expertise. This article arose from a joint seminar presentation at the Leiden Interdisciplinary Migration Seminar during April 2018, in which both authors gave a short talk about their own respective research. Prior to this, neither knew anything about the other's work and were astonished by how similar their respective presentations were. We feel this strengthens our argument, as the comparison between these two mining regions was not deliberately sought out on the basis of pre-existing knowledge about similarities between them.

Much detailed work has been undertaken on race and labor in individual mines and mining regions and historians of these places will, hopefully, recognize much of what is discussed in this article from their own case studies. What is missing is an appreciation of how widespread this was, and that, until well into the twentieth century, in mines across the globe, racial hierarchies and occupational hierarchies were virtually the same thing. It seems likely that the lack of comparative work has contributed to inhibiting this insight, and there is virtually no comparative work on either of the regions discussed in this article, despite both being the focus of significant academic research and production for several decades. ${ }^{1}$

This reflects a wider neglect of the comparative dimensions of mining. In the introduction to a 2005 edited collection on coalfield societies, Stefan Berger notes 
that "conscious comparisons remain the exception rather than the rule," an observation that remains true. ${ }^{2}$ Yet many studies have commented on, as Martin Bulmer's classic article on mining communities put it, "the similarities between mining settlements of different types in different societies at different stages of economic development." In this sense, many studies of mining regions and mineworkers are implicitly comparative by remarking on the kind of similarities that distinguish these places, and occasionally scholars have remarked on the prevalence of racial hierarchies in the mining industry beyond their individual site of study. These similarities and differences are only rarely subjected to sustained analysis, however. ${ }^{4}$ There are some studies that have engaged in this kind of comparative analysis of different mines and mining regions, and this has primarily focused on coal mining, though there is also some work on copper mining and gold rushes. ${ }^{5}$

The paucity of the comparative history of mining is, Stefan Berger explains, "not least because [conscious comparisons] are time-consuming, difficult and fraught with methodological problems." made a plea to mining historians "to avoid local parochialisms and use transnational comparative and cultural transfer history to shed light on both commonalities and differences of mining communities." ${ }^{\text {" }}$ Units of comparison should be appropriate and the purpose of comparison defined. Furthermore, Andrew Taylor cautions that concepts for comparison "must come first and they can be deployed in specific historical contexts," instead of "forcing cases into theoretical straitjackets." ${ }^{\text {" }}$ When these methodological issues are addressed, comparative studies have "tested a range of conceptual ideas in history and established typologies that have brought about a better understanding of the differences and similarities between related historical

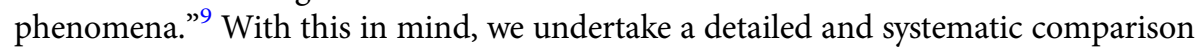
on labor in two different mining regions-one in central Africa, the other in northern China. Our comparative study aims to investigate the close relationship between mining and imperial formation by examining the role of race in organizing work and daily life in these two mining regions. In his most recent effort to provide a framework for comparative mining history, Berger identified eleven themes in mining history-the equivalent of Taylor's concepts-that he contends transnational or comparative perspectives would "underline the fruitfulness of looking beyond one specific locality, region, or nation." 10 Our comparative study of race and imperialism is our humble contribution to Berger's list of themes.

In this comparison, we draw inspiration from those scholars who have written on how racial thinking informed and structured the organization of labor processes and relations, and how racial divisions shaped or "fractured", to paraphrase British sociologists Robert Miles and Annie Phizacklea, class formation, something that American and South African historians have been particularly alert to. ${ }^{11}$ According to David Roediger and Elizabeth Esch, capital depends on produced differences among labor for its profits and in the era where scientific racism and industrial production existed, racial knowledge enabled management to justify differential treatment of a highly diverse multinational working population and to rank these workers based on these differences. These forms of racialized labor management were exported alongside the global expansion of US corporations and the global migrations of American engineers. ${ }^{12}$ The spread and deployment of racial thinking 
in labor management by American firms and professionals has been traced by numerous scholars, notably in Daniel Bender and Jana Lipman's edited collection, and in Julie Greene's history of the construction of the Panama Canal and Jason Colby's history of US, corporate-owned banana plantations in Costa Rica. ${ }^{13}$ Some of this work has specifically focused on the mining industry. ${ }^{14}$

These works underscore the salience of racial knowledge in the management of industrial labor while revealing the constructedness of race categories. Race, according to Stuart Hall, "is a discursive construct, a sliding signifier," in which meanings are assigned to somatic or biological differences between peoples. ${ }^{15}$ The ascription of these meanings onto the body often occurred "within the practices and operations of relations of power between groups." ${ }^{16}$ In other words, the process of classifying peoples based on immutable physical or biological differences is intimately linked to the process of establishing dominance. Stuart Hall states in his earlier essay that race is "the modality in which 'class' is 'lived', the medium through which class relations are experienced." 17 This comparative analysis of two mining sites illuminates Hall's contention. We recognize crucial differences in Japanese, Belgian and British imperial processes that shaped the particularities of each mining site. Yet, we found compelling similarities that demand attention. In both cases, the mining site was as much a site for producing racial differences as it was a site for producing material wealth.

\section{Mining and Imperialism}

Mining has been central to the expansion of empires in the last few centuries, "the major pioneers in opening up the world to imperialism," as Eric Hobsbawm put it." ${ }^{18}$ Natural resources extracted from mines were fundamental to the economic prosperity, political influence, and military strength of empires, and there is a longstanding connection between control of natural resources and imperial power in the understanding of empires. Often, mineral resources have been connected to Euro-American empires, but, as Sanjay Subrahmanyam reminds us, several features "typically associated" with European imperialism could be applied to Asian examples, and here we look at case studies from the British, Belgian, and Japanese empires. ${ }^{19}$

There was a close relationship between mining and imperialism in both our case studies as industrial mining on a massive scale began following imperialist intervention and production became integral to the war economies of their respective colonial powers. In the late nineteenth and early twentieth centuries, emerging imperial powers Russia and Japan competed over economic and political influence in Northeast China. Coal extraction began at Fushun in 1900, under the auspices of Russo-Chinese mining companies financed by Russian capital, but the Fushun coalfields, along with other Russian assets in the region, were seized by Japan following their victory in the 1904/5 Russo-Japanese War. Imperialist rivalry between Belgium and Britain in Central Africa, motivated partly by expectations of mineral wealth in the region, led to the seizure and division of the Central African Copperbelt between the two powers in the 1890s. Abandoned mine workings, some dating back centuries, gave some clue about the riches of the region, but the extent of copper deposits was only realized from the late 1900 s and precipitated a huge mining boom. 
The sheer size of these mineral deposits ensured their importance to the economies of the imperial powers that controlled them. Coal deposits at Fushun were estimated to be 750 million tons in the 1920s, and later revised to 950 million tons, with a main seam that spanned about $16 \mathrm{~km}$ in length and $3 \mathrm{~km}$ in width. In 1905 , the Japanese Army mining engineer in charge of the survey reported to his superiors that the coal deposit in Fushun exceeded total Japanese coal reserves by thirteen-fold, making Fushun an invaluable source of cheap energy for securing Japan's economic presence in Manchuria. Annual coal production peaked at 10.34 million tons in $1937 .^{20}$ The Central African Copperbelt was, in this period, the largest copper deposit in the world, containing approximately 140 million tons of copper in a region around $500 \mathrm{~km}$ in length and $30 \mathrm{~km}$ wide. ${ }^{21}$ Mining operations began first in Katanga Province in Belgian Congo in the late 1900s, then across the newly-established border in Northern Rhodesia as further deposits were discovered there, and production increased rapidly. Between 1930 and 1939, over 16 percent of global copper output came from the Copperbelt. ${ }^{22}$

The mineral output from these regions directly supported imperial economies. All mining in Katanga was controlled by Union Minière du Haut Katanga (UMHK), in which the colonial state had a substantial stake, while two private companies controlled the mines in Northern Rhodesia: Rhodesian Anglo American (RAA) and the Rhodesia Selection Trust (RST). ${ }^{23}$ Copper went largely to Britain, and copper from the Copperbelt proved critical for the country during the First and Second World Wars for the manufacture of arms and munitions. ${ }^{24}$ In peacetime, UMHK's output first supplied Belgium's modest demands, then the remainder was sold on the London market, and the 1932 Ottawa Accords, which gave preferential access to British markets for Commonwealth products, meant that most copper mined in Northern Rhodesia went to Britain. ${ }^{25}$ Moreover, taxation on revenues from copper production bankrolled colonial rule in the region.

The role of coal in Japanese colonialism was more subtle. The Japanese state formed a joint stock company, the South Manchuria Railway (SMR), to manage the assets it seized from Russia. Japan, however, was not the main destination for Fushun coal. The Japanese Coal Owners' Association succeeded in restricting the import of Fushun coal to Japan on the grounds of unfair competition. Instead, Fushun coal fueled a growing Japanese-controlled industrial complex in Manchuria, and 77 percent of Fushun coal output was sold to public utilities, iron works, and railway and shipping companies in the region. ${ }^{26}$ The SMR, as Ramon H. Myers observes, was given the guise of a commercial enterprise that would allow "Japan [to] quietly and gradually [expand] its influence in southern Manchuria while developing economic interdependency with the region." ${ }^{27}$ Coal also supported the Japanese war effort, providing a source of petroleum after new methods of distilling petroleum from the oil shale discarded in coal mining and freeing Japan from dependence on US oil fields.

\section{Racial Division of Labor}

Existing populations in each region could not satisfy the huge demand for labor, and so companies in both places relied upon migrant labor systems. However, the structure of the workforce at both sites meant that this involved the recruitment of two 
different migrant workforces from separate labor markets. The division between these two migrant workforces was partly one of skill but was fundamentally a racial division. ${ }^{28}$ At Fushun, unskilled Chinese and skilled Japanese workers were recruited; on the Copperbelt, it was skilled white workers and unskilled African workers. Throughout this period, over 80 percent of Fushun's workforce was composed of Chinese men and around 90 percent of the Copperbelt workforce were African men, and almost all manual work was performed by this section of the workforce. ${ }^{29}$

African and Chinese labor was secured through a migrant labor system. At Fushun, SMR secured labor supplies from existing flows of migrant labor to Manchuria that had begun in the late nineteenth century when the imperial Qing state allowed the free movement of Han Chinese to the region. In contrast, UMHK had to create its own migrant labor networks, and forcibly recruited labor from elsewhere in Belgian Congo, as well as neighboring colonies, and even attempted to recruit labor from China in $1913 .{ }^{30}$ Other companies on the Copperbelt, too, formed their own labor recruitment organizations to obtain African labor when their operations began in Northern Rhodesia in the late 1920s.

Mines in both regions absorbed vast amounts of labor partly due to the scale of production but mostly because, at first, production relied heavily on unskilled labor. Mining operations on the Copperbelt were almost entirely unmechanized when production began in Katanga in 1911. Copper oxide ores were discovered relatively close to the surface, which enabled extraction through open pit mining and African workers extracted copper ore by hand, concentrating on higher-grade ore, which was then shipped to Belgium for processing as there was initially little development of surface plants. ${ }^{31}$ Similarly, at Fushun, from 1907 to 1930, the extraction and haulage of coal from the face to shaft entry in the underground pits depended entirely on manual labor and hand tools, namely pickaxes and shovels, all tasks performed by Chinese workers. Work at the coalface involved a single crew of hewers working with pickaxes and then moving the cut coal with hand shovels into coal cars.

Persistent labor shortages hastened mechanization. Labor supplies in north China depended upon the stability of Sino-Japanese relations, which deteriorated in the late 1920s, and hit a nadir when Japan established a puppet regime in Manchuria in 1932. Movements of migrant labor were disrupted and, when they resumed, SMR found themselves competing for Chinese labor with other industrial enterprises established by the new regime. The beginning of large-scale mining operations in Northern Rhodesia increased competition for labor on the Copperbelt. Steam shovels were introduced in UMHK's open pits, and the proportion of copper ore extracted by hand fell from 90 percent in 1923 to 16 percent in $1929 .^{32}$ By 1930 , UMHK could boast that "operations were mechanized to the greatest extent, so as to reduce the workforce to a minimum." ${ }^{33}$ At Fushun, electric- and steam-powered drills replaced pickaxes in coal extraction, and conveyor belts and electric railcars were introduced in underground workings. Underground mining operations established by RAA and RST on the Copperbelt were heavily mechanized from the outset, as the companies worried about potential shortages of African labor.

Race was the basic principle for organizing the labor process. Work regarded as unskilled was performed by Africans on the Copperbelt and Chinese workers at Fushun, who performed almost all manual work at both sites. Colliers, diggers, brace 
workers, and rail-track workers were all Chinese at Fushun, while on the Copperbelt it was Africans who drilled and cleared copper ore in underground mines and open pits. Professional and managerial positions-mining engineers, pit supervisors, metallurgists, geologists, etc.-were all occupied by Japanese labor at Fushun and by whites on the Copperbelt. It is worth noting that in both places mining work was also highly gendered: All workers employed underground and in the open pits were male. The few female workers were mostly from the top of the racial hierarchy-there were female Japanese telephone operators and laboratory technicians at Fushun and white women were employed in medical or clerical positions on the Copperbelt.

Significantly, there was no legislation in either place enforcing this labor structure and no official company policy as, in both cases, it appears that the policy was so obvious that it did not need to be formally articulated. SMR, for instance, had no official prohibition against hiring Chinese workers for management or professional positions, and yet in 1926, not a single Chinese person was employed in these positions while 8,689 Japanese were. ${ }^{34}$ There was likewise no legislative or corporate policies that restricted African workers to particular jobs on the Copperbelt mines, yet no African, regardless of the job they performed, had authority over any white worker. ${ }^{35}$ At Fushun, this informal policy persisted into the 1930s and 1940s, despite shifts in Japanese imperial ideology and a tighter labor market. Following the establishment of the Japanese puppet regime Manchukuo in 1932, Japanese imperial ideology emphasized commonalities between the colonizer and the colonized while maintaining the racial superiority of the Japanese people. Labor management practices reflected the prevailing racial ideologies of the respective imperial powers where racial superiority was based on supposedly immutable characteristics of biology and culture.

The racial division of labor in both mining regions was obvious, but it was not fixed and could shift depending both on the requirements of the mining companies and demands from the mining workforces. As we will see, the racial division of labor was something not only initiated and imposed by the mining companies in these years; it was also shaped by the agency of their workforces. Mechanization increased the need for skilled labor but complicated and blurred the racial division of labor, as will be discussed below. First though, this article turns to the different forms that the racial hierarchy on the mines took.

\section{Reproducing the Racial Labor Hierarchy}

Reproducing and sustaining this racial labor hierarchy required continual intervention from the mine management and from the sections of the workforce. Differences among racial groups were ascribed less through textual means and more through labor management strategies and practices. Below, we discuss three strategies and practices in which mine management enacted throughout the period 1907-1945 to ensure the continuation of a racial labor hierarchy.

\section{Recruitment}

African and Chinese workers were recruited on different contracts than white and Japanese workers, and from different labor markets. Initially, African and Chinese 
workers were predominately short-term labor migrants who rarely remained at their respective mines long enough to acquire greater skills. Fushun Mine was supplied with Chinese workers from the well-established migration route between North and Northeast China. Each year, after the planting season, hundreds of thousands of young men from rural North China travelled by foot, rail, buses, and steamships, to Manchuria for short-term employment and returned home for the harvest season. This meant that, even in 1940, the average length of employment for unskilled Chinese workers was less than six months. ${ }^{36}$ Chinese labor contractors, who had autonomy over recruitment and supervision, were used by SMR to recruit hewers, blasters, haulers, timberers, and unskilled workers. These labor contractors were originally independent but, in the early 1920s, became salaried workers under the supervision of Japanese pit supervisors.

UMHK, too, initially used labor recruiters to source African labor from rural areas across central Africa and used violence and repression to meet their labor demands. ${ }^{37}$ Until 1925, the majority of this workforce came from neighboring colonies and were recruited for contracts of six to eight months after which they had to return to rural areas. A similar system was adopted in Northern Rhodesia, where African men were compelled to seek wage work following the imposition of taxes, which had to be paid in cash, in 1905 in Northern Rhodesia, then in 1912, in Katanga Province. ${ }^{38}$ Active recruitment of long-distance migrant labor slackened and then ceased following the Great Depression as the economic crisis transformed labor scarcity into surplus. After 1931, all African labor at Northern Rhodesian mines was "voluntary"; that is, Africans arrived at the mines seeking work and, that same year UMHK ceased recruitment outside Belgian-controlled territories. Still, the average length of employment remained short, and even in the late 1930s, some Copperbelt mines had an annual labor turnover of over 80 percent. $^{39}$

Recruitment strategies produced segmentation in the mine's workforce. On the Copperbelt, recruitment of white labor was targeted at skilled workers from mining and industrial centers elsewhere in the world. In 1929, RAA forecast that the problem of attracting "trained white labor will no doubt solve itself. . . Men will come from South Africa, from Britain, Australia, New Zealand, Canada, the United States and the Continent of Europe." ${ }^{\prime 0}$ This is precisely what happened at UMHK's mines in the 1910s and 1920s. In the same way, SMR targeted recruitment of experienced miners from Japanese mines in Kyushu to work as technicians and pit supervisors at Fushun. Engineers and managers were recruited from among the top-ranking Japanese universities, such as Tokyo University and Doshisha University. Mining engineers trained at American universities, or with extensive experience in North America, originally occupied to the top positions on the Copperbelt, but these were steadily replaced at UMHK by men trained in Belgium and at RAA and RST by those trained in Britain and South Africa.

\section{Dual wage structure}

A dual wage structure was implemented at both Fushun and the Copperbelt where the wages mineworkers received related to their racial categorization, rather than to the work they performed. Wages and other forms of renumeration were calculated on a standardized basis, another way in which a racial division was coded into the 
labor structure, and workers at the top of the racial hierarchy received considerably higher wages. In 1926, at Fushun Mine the average daily wage (excluding supplementary benefits) for a Japanese yōin worker was 2.48 yen while that for a Chinese yōin worker was 0.68 yen. $^{41}$ In addition to standardized wages, SMR employees also received added benefits of paid vacation days, travel reimbursement, better company housing and food provisions, language tuition grants, collective relief funds, healthcare, a variety of allowances for family, underground mining work, and military service. $^{42}$ In the rare instances where Japanese and Chinese were employed at the same job and rank, the salary of the Japanese worker was over three times higher than that of the Chinese workers.

The same wage structure was in place at the Copperbelt mines, though the gap between white and African wages was significantly larger than the wage gap between Japanese and Chinese workers. In 1940, African surface workers on the Northern Rhodesian Copperbelt earned an average of $0.8 \mathrm{~s}$ per shift while underground workers earned an average of $1.1 \mathrm{~s}$ per shift. The highest paid African workers earned only $2 \mathrm{~s}$ per shift. ${ }^{43}$ In contrast, the lowest paid white mineworker earned a basic wage of $20 \mathrm{~s}$ per shift in 1940, and white artisans earned 28s per shift, plus supplementary benefits. ${ }^{44}$ Similarly, in 1935, the wage bill for UMHK's 596 white workers was higher than for its wage bill for 10,000 African workers. ${ }^{45}$ Renumeration for African mineworkers was supplemented with food rations, which marginally reduced the huge disparity between white and African wages, and in the 1930s, African mineworkers received between 51 percent and 66 percent of their wages in cash, depending on which company they worked for. ${ }^{46}$

In other ways, however, the racial division in wages at Fushun was starker. Calculating the exact disparity between Chinese and Japanese wages is complicated by the fact that they were paid in different currencies, and the exchange rate between the two fluctuated considerably over this period. ${ }^{47}$ On the Copperbelt, all workers were paid in the currency of the respective colony, either Congolese francs in Belgian Congo or pound sterling in Northern Rhodesia, making for easier comparison between different section of the workforce. ${ }^{48}$ At Fushun Mine, Japanese workers were paid in Japanese yen and Chinese workers in the local currency known as the silver coin or xiaoyangyin. While Japanese workers could simply use Japanese yen for daily expenses and savings, the Chinese workers had to convert their wages from silver coins to Mukden notes for daily expenses and to Japanese yen for savings. Each conversion incurred risk and loss in value, especially during the volatile period between 1926-1931. For instance, in May 1926, 317 Mukden notes exchanged for 100 Japanese yen. It rose to 650 in December 1926 and 850 in March 1927. ${ }^{49}$ When tensions in Sino-Japanese relations escalated after the Kwantung Army assassinated Zhang Zuolin in 1928, all Chinese banks in Manchuria ceased currency conversions and all Chinese businesses had to accept only local currencies, not Japanese yen. Considering the volatility of exchange rates and instability of local currencies, the use of silver coins to pay Chinese workers ( yoin) should be calculated as a further wage reduction.

The underlying assumption about inherently lower living standards justifying lower wages was the same in both cases. In its public relations materials, the SMR claimed that "Chinese labor, owing to the lower standard of living, lesser efficiency 
and ample supply, received less in wages than Japanese." ${ }^{50}$ On the Copperbelt, this racist assumption increasingly came under assault by African workers. In 1945, one African miner from Mufulira Mine in Northern Rhodesia complained at a meeting with colonial officials that:

We have been told again and again that our cost of living is very low and the cost of living for Europeans is very high. I wonder whether that would bear comparison with what is given to both people. What we would like to see is a narrowing of the great gap between the pay of the two races. ${ }^{51}$

\section{Housing and recreation}

Mineworkers at Fushun and the Copperbelt worked together and lived apart. All mineworkers in both regions were provided with company housing and recreational, entertainment, and medical facilities, but the type and quality of these depended on race. Spatial residential segregation was ensured through the construction of new company towns to house the mining workforce on the basis of race. On the Copperbelt, this was assisted by the fact that there were no substantial urban centers in the region before the onset of industrial mining. Katanga's largest urban center, Elisabethville (now Lubumbashi), built around UMHK's smelter plants, was established in 1910, with European and African sections separated by a 170m wide strip, later expanded to $500 \mathrm{~m}$ "to assure the segregation of the city along neat racial lines." 52 The same model was followed across the border in Northern Rhodesia, where company housing for African and white mineworkers was usually constructed on opposite sides of the mine to ensure racial segregation on the basis of physical separation.

Comparable patterns of urban development and residential segregation existed in Fushun. The start of coalmining in 1900 attracted an influx of newcomers and prompted a boom in construction, reversing a decades-long trend of population decline. Chinese mining workers transformed Qianjinzhai from a village, which lent its name to a nearby underground pit, into a thriving town. Urban development occurred along racial lines after the SMR took over the coalfields. The SMR designed and built company towns: New Town and then Yong'antai. The latter, whose construction started in 1924 and ended in 1932, formalized residential segregation at Fushun with its designed separate areas for Japanese and Chinese workers. Unlike the Copperbelt, SMR provided housing for only formal employees and not contract labor, and the majority of Chinese workers were contract labor. Despite this provision, Japanese and Chinese SMR employees had different criteria of qualifying for housing: All Japanese employees automatically qualified, but Chinese employees had to work for over three years and retain exemplary conduct at work in order to qualify. ${ }^{53}$ Furthermore, Japanese and Chinese employees lived in separate buildings. ${ }^{54}$

Leisure and recreation facilities were provided in Yong'antai for company employees, and arranged so that Chinese and Japanese workers' leisure time was spent in separate spaces. An entertainment complex constructed by SMR in the Chinese section, located in the southern side of Yong'antai, contained a Laojun temple, Chinese opera stage, teahouses, shops, and brothels. Recreational facilities for Japanese employees and residents, which included parks, a swimming pool, a skating rink, a 
sumo ring, a rugby field, tennis courts, a baseball diamond, and athletic fields, were located in the northern side of Yong'antai. ${ }^{55}$ Similarly, separate bars, sports clubs, and other recreational facilities were established in the mine townships for white and African workers. Leagues and competitions for a wide variety of sports were established-including football, rugby, tennis, and golf-but white and African teams did not play against each other.

\section{Labor Activism and the Racial Hierarchy}

Workers themselves were not passive recipients of racial ideology and acted both to contest and to enforce the racialized division of labor in the mines. It was not unusual to find protests of Chinese and African mineworkers against Japanese and white supervisors for unfair treatment. One of the largest workers' protests in Fushun Coalmine occurred in May 1916, when five hundred Chinese mineworkers amassed spontaneously to demand the release of a Chinese mineworker who had been assaulted by a Japanese supervisor. ${ }^{56}$ On the Copperbelt, there were mass strikes by African mineworkers in Northern Rhodesia in 1935, and at mines on both sides of the border in 1940-1941, but these strikes were harshly repressed. ${ }^{57}$ Perhaps because of their subaltern status, or the transience of the workforce, Chinese and African workers seldom sustained their workplace activism or organized themselves collectively in their challenges of the racial order in this period. In contrast, we find privileged workers-Japanese mineworkers in Fushun Coalmine and white mineworkers in the Copperbelt-forming collective organizations and deploying the imperial ideology to preserve and enhance their position in the racial hierarchy.

Collective organization among workers at the apex of the racial hierarchy emerged in response to threats to that position from their employers. The commitment of both mine managements in the Copperbelt and Fushun to the racial hierarchies was equivocal, and they could be altered if profits were threatened or the needs of production changed. Starting with the recession in the mid-1920s and the Great Depression in the years 1929-1931, SMR management, in the face of declining profits, reduced the wages and bonuses of its Japanese employees, laid off its Japanese workers, and replaced them with Chinese workers at lower wages. ${ }^{58}$ On the Copperbelt, UMHK did the same during the Great Depression, laying off hundreds of white workers and replacing them with African workers, who were paid much lower wages.

Japanese mineworkers in Fushun Coalmine formed a branch of the SMR employees' association in January 1927. This company-wide association was formed with the stated goals of enhancing the participation of blue- and white-collar Japanese SMR employees in the management of the company and of holding the company's directors accountable to its Japanese employees. ${ }^{59}$ To Japanese mineworkers in Fushun Coalmine, this company-sanctioned association provided a safe way to further their agenda, which consisted of gaining parity with white-collar SMR employees and ensuring superiority over Chinese workers. As blue-collar workers holding the lowly yōin rank, these Japanese mineworkers were more likely than their white-collar compatriots to face proportionally larger wage reductions or dismissals. For instance, when mine management adjusted wages in the early 1920s to account for high inflation, the white-collar professionals received a maximum of 60 percent increase in 
their salaries and the blue-collar workers a maximum of 40 percent (it should be noted that the Chinese employees received a maximum increase of only 15 percent). ${ }^{60}$ Japanese mineworkers from Fushun Coalmine pushed the SMR employees' association to take up economic issues like extending retirement bonuses to blue-collar workers and to take industrial actions like a company-wide strike. ${ }^{61}$ But their push met with considerable resistance from white-collar professionals who rejected taking up economic issues and preferred taking a conciliatory approach. ${ }^{62}$ The latter group eventually prevailed.

White mineworkers in the Copperbelt were more militant than Japanese workers in Fushun Coalmine in their mobilization to defend the racial hierarchy. In 1920, white mineworkers at UMHK formed a union and embarked on violent strikes demanding wage increases and that that skilled work be limited to whites, but the company and colonial administration had swiftly crushed the movement. In 1936, white mineworkers on the Northern Rhodesian Copperbelt formed a racially-exclusive trade union, and subsequently embarked on repeated wildcat strike action during the Second World War to win major wage increases, a closed shop for the union, and a color bar preventing African mineworkers from undertaking skilled work. This action was closely informed by the replacement of white mineworkers with African mineworkers at UMHK's operations, which had itself been partly motivated by white industrial unrest. These strikes by white mineworkers at UMHK in the early 1940 s were repressed like the strike in $1920 .^{63}$

The relationship between privileged workers and empire might explain the difference in the militancy of privileged workers at both sites. Unlike white mineworkers in the Copperbelt, Japanese mineworkers in Fushun Coalmine strongly identified with the Japanese imperial state, to the point of accepting the marginalization of their economic demands in the employees' association. When the Japanese army invaded Manchuria on 18 September 1931, Japanese mineworkers celebrated what they saw as a necessary step toward "building a new utopia." ${ }^{4}$ The invasion also marked increased involvement of the Japanese military in the administration of Manchuria and SMR. Dissidents were arrested, dismissed, or demoted. The founding of the nominally independent Manchukuo nation-state deepened Japanese mineworkers' identification with the imperial project. ${ }^{65}$

On the Copperbelt, white workers had a more ambivalent relationship with the empire, and often sought to justify their privileged position in relation to their skills and position in imperial labor markets. Many white workers involved in industrial unrest at UMHK in 1920, including the key instigators, were not Belgian nationals and had no loyalty to Belgium, the colonial power in Belgian Congo. ${ }^{66}$ After this strike, UMHK primarily recruited its white workforce from Belgium and closer identification with Belgium's colonial project-stressed in UMHK's recruitment material - may have encouraged loyalty to the company and quenched militancy, at least until 1940, when strikes revived after the fall of Belgium. White mineworkers in Northern Rhodesia, though largely British subjects, exhibited little loyalty to the British Empire and regarded themselves as part of an international but highly racialized working class. Many were more than willing to use the circumstances of the Second World War, when Britain's need for copper for its war effort was greatest, as an opportunity to improve their pay and conditions through strike action, and to enforce the racial 
division of labor. ${ }^{67}$ Putting aside the difference in the militancy of privileged workers, there remain significant similarities in the attitudes of mine management toward labor activism. Mine management did not welcome any attempts at collective organizing of Japanese and white mineworkers, which threatened management's control over labor relations. Mine management increasingly saw mechanization as a means of regaining control of labor relations and mining operations.

\section{Mechanization and the Racial Division of Labor}

In an overview of migration and ethnicity in coal mining around the globe, Ad Knotter concluded that there was a clear difference between the recruitment of skilled miners and the recruitment of unskilled workers, and recruitment efforts of the latter were "often targeted at ethnic groups of a lower social status" because they were unskilled and considered culturally and racially inferior by the dominant ethnic group. Knotter connects this to the organization of work by pointing out that the recruitment of unskilled workers often occurred alongside technological developments and deskilling so that "ethnic divisions in the workforce were therefore blurred with divisions of skill and hierarchy." ${ }^{16}$ We see similar processes at the mining sites we examine here, except that mechanization disrupted more than "blurred" existing racial hierarchies when increased numbers of African and Chinese workers joined the ranks of skilled workers.

Mechanization resulted in a greater division of labor, increased specialization of jobs, and greater demand for skilled labor. On the Copperbelt, persistent worries about labor shortages prompted mechanization, and skilled jobs were initially monopolized by white workers, and mechanization therefore led to a substantial increase in their numbers. In 1914, UMHK employed only 175 whites and 3,868 Africans. ${ }^{69}$ By 1930, the three mining companies on the Copperbelt collectively employed over five thousand whites and almost thirty-four thousand Africans. ${ }^{70}$ As already noted above, this situation quickly changed in the early 1920s, following strikes by white workers, UMHK began training African workers to perform skilled work and replace more expensive white workers. ${ }^{71}$ This was part of a policy of labor stabilization, involving a move away from migrant labor and the establishment of a semi-permanent African workforce composed primarily of married men who would work on the mines for longer periods and undergo training to perform the more diverse and skilled jobs required in mechanized operations. Housing, sanitation, and rations were improved, and, as a result, average length of employment of African mineworkers progressively increased. ${ }^{72}$ RAA and RST subsequently sought to implement the same policy.

A similar process was underway at Fushun in the same period. Prior to mechanizing work at the coal face, the coal miner performed the tasks of extracting and hauling coal with pickaxes, shovels, and occasionally jute sacks instead of coal cars. After mechanization, manual extraction and haulage was replaced by a drilling crew that drilled holes to insert explosives, a blasting crew that handled the dynamiting, a hewing crew that broke up larger pieces of coal, and a transport crew that operated the conveyor belts. Each crew performed a specialized task, and this specialization of work meant that the hiring and treatment of Chinese labor had to be differentiated 
according to the type of work. Skilled Chinese workers remained at the mine for longer. A 1940-mine company survey revealed that at least 80 percent of skilled Chinese worker had been employed at the mine for more than five years. ${ }^{73}$

The need for more skilled labor complicated the existing racial division of labor. In Fushun Coalmine, the racial division of labor tended to privilege Japanese labor over Chinese labor in supervisory, administrative, skilled technical positions. Fushun Coalmine employed both Chinese and Japanese labor in low-level technical and supervisory positions. In 1921, there were 42 Chinese and 234 Japanese foremen, and 17,584 Chinese and 2,378 Japanese low-level technical workers. ${ }^{74}$ We can see here a clear preference for Japanese labor in supervisory positions and a closer examination of the low-level technical positions reveals that more Japanese workers were usually employed in the administrative positions, such as clerical workers and drafters, and in technical positions at key points of mining operations, namely drivers, coal inspectors, and security guards. These patterns of employment continued into the 1930s and 1940s, though with a significant change. After mechanization, the number of Chinese workers employed in mid-level technical positions rose from 0 in 1926 to 3,648 in $1937 .^{75}$

However, while African and Chinese workers began to undertake a greater range of skilled jobs at their respective mine sites and complicated the racial division of labor, other forms of racial segregation remained rigid. Company housing, welfare provision, and pay-scale all remained racially divided, meaning that, for instance, no African or Chinese worker moved into housing provided for racially privileged workers, even though they performed work tasks previously done by these workers. This had evident financial benefits for the mining companies concerned.

What we see here is that a rigid racial division of labor was not in the interests of the mining companies, whose labor requirements were changing. Instead, these companies sought to alter and manage the racial division of work but not abolish it. This was done primarily by moving this division up the occupational hierarchy of the mine. The key tool for management of the racial division of labor was control over training opportunities. At Fushun, formal employment was a prerequisite to access special privileges such as taking supervisor examinations that were needed for internal promotion and funding to acquire technical knowledge and skills at universities, technical institutes, and language schools in Japan, Europe, the United States, and China. ${ }^{76}$ SMR excluded most Chinese workers from formal employment and hired them as contract labor, meaning that only select numbers of Chinese workers were allowed to acquire certified technical skills and knowledge. In 1937, Chinese workers constituted 90 percent of Fushun's total workforce, but only 34 percent of the formal workforce and 7 percent of the skilled workers. ${ }^{77}$ Across the period 1910 to 1940 , there were never more than six hundred Japanese contract workers, and seldom less than twenty thousand Chinese contract workers. ${ }^{78}$

Control over workplace training was more contested on the Copperbelt. UMHK exercised tight control over the racial division of labor. African workers employed by the company were trained to operate heavy machinery like steam shovels or as artisans, such as carpenters or fitters, but ultimately they were under the supervision of a white employee. All African mineworkers working for RAA and RST were similarly always supervised by white workers and some were trained to perform semi-skilled work in 
the 1930s, such as driving lorries and bricklaying, but training schemes were implemented slowly and unevenly. ${ }^{79}$ Moreover, though the companies in Northern Rhodesia sought to emulate the labor policy implemented by UMHK, they were effectively prevented from doing so in the early 1940s by collective action by their white workforce, who blocked the training and promotion of African workers.

At both sites, disruptions to the racial division of labor arising from mechanization and its attendant labor requirements did not ultimately dismantle the racial hierarchy. Recruitment practices, a dual wage structure, and residential segregation-all which structured the racial hierarchy of labor-remained intact. Although a minority of Chinese and African workers were trained as skilled workers, their positions in the racial hierarchy remained subordinate that of Japanese and white workers, even if their skills and jobs were largely similar. Despite the impact of mechanization on the division of labor, African and Chinese workers did not occupy positions of authority in the industry, and it was inconceivable to both white and Japanese managements and workers that the colonized subjects could have become managers.

\section{Conclusion}

The compelling similarities of two disparate mining sites, as analyzed in this comparative study, highlights the complex intersection of race and class, and the contradictory logics of capitalism and imperialism. The category of "race," to paraphrase Ann Stoler and Frederick Cooper, underpinned the organization of mining work and daily life, but it was also disavowed and challenged. ${ }^{80}$ Mine managements instituted racially organized work processes and relations but they also demonstrated a willingness to alter the racial organization of labor at critical moments of lowered profits and production. Moreover, mine managements were not the only source of racial thinking and practices. White and Japanese workers became defenders of racial thinking and practices when layoffs, wage reductions, and the training of African and Chinese workers threatened their privileged positions. Racial practices kept the majority of African and Chinese mineworkers at the bottom of the labor hierarchy, with a small minority of skilled African and Chinese mineworkers emerged in spite of resistance from privileged workers. For each of these actors, race was deployed as often as it was disavowed for the protection of their respective interests. Yet, each episode of deployment or disavowal entrenched and refined the racial division of labor, further reifying differences among the groups.

We do not want to overstate the commonalities between these two places and there were important differences. They were similar, not the same. Forms of racial segregation were evidently starker in colonial Africa and the division between African and white workers on the Copperbelt mines was more firmly demarcated than the divide between Chinese and Japanese workers at Fushun. There were also differences in capital accumulation and the position of each territory in their respective empires. Coal from Fushun was used by Japan as part of broad-based industrialization of the region thereby consolidating imperial control over the territory. Some industrialization occurred on the Copperbelt outside the mines, especially in Belgian Congo, but it was more limited and capital primarily flowed back to metropolitan centers.

Nevertheless, the comparison of these two distant mining sites has given some indication about the centrality of race in the mining industry in the early twentieth 
century, something which has been underappreciated. We hope that this article will encourage further comparative work in mining and labor to test this claim.

\section{Notes}

1. The authors are aware of only two explicitly comparative works about the Copperbelt: Bruce Fetter, "Changing Determinants of African Mineworker Mortality: Witwatersrand and the Copperbelt, 1911-1940," Civilisations: Revue internationale d'anthropologie et de sciences humaines 41 (1993): 1-9, and Chilufya Chipasha Luchembe, "Finance Capital and Mine Labor: A Comparative Study of Copper Miners in Zambia and Peru, 1870-1980" (Ph.D. diss., University of California, 1982). The authors are not aware of any historical work that situates the history of Fushun Coalmine or the history of mining in China in a comparative perspective.

2. Stefan Berger, "Introduction," in Stefan Berger, Andy Croll and Norman LePage, eds., Towards a Comparative History of Coalfield Societies (London, 2005), 3. Ian Phimister makes the same point; see Ian Phimister, "Global Labor History in the Twenty-First Century: Coal Mining and its Recent Pasts," in Jan Lucassen, eds., Global Labor History. A State of the Art (Bern, 2008), 589. See also, Klaus Tenfelde, Towards a social history of mining in the 19th and 20th centuries: International mining history congress (München, 1992), and Ad Knotter, "Mining," in Karin Hofmeester and Marcel van der Linden, eds., Handbook. The Global History of Work (Berlin, 2018), 237-258.

3. Martin Bulmer, "Sociological Models of the Mining Community," The Sociological Review 23 (1975): 61

4. Take, for instance, Jon Belshaw's remark in his work on British miners on Vancouver Island, Canada that "ethnic and racial division was virtually endemic to 19th century mining communities." John Belshaw, "The British Collier in British Columbia: The Archetype Reconsidered," Labor/Le Travail 30 (1994): 30.

5. John Laslett, Colliers Across the Sea: A comparative study of class formation in Scotland and the American Midwest, 1830-1924 (Urbana, IL, 2000); Ad Knotter, "Migration and Ethnicity in Coalfield History: Global Perspectives," International Institute for Social History 60 (2015): 13-29; Phimister, "Coal Mining," 573589; Kayoko Yoshida and Reiko Miyauchi, "Invisible Labor: A Comparative Oral History of Women in Coal Mining Communities of Hokkaido, Japan and Montana, USA, 1890-1940," in Jaclyn J. Gier and Laurie Mercier, eds., Mining Women (New York, 2006), 136-152. For copper, see Janet Finn, Tracing the Veins: Of Copper, Culture, and Community from Butte to Chuquicamata (Berkeley, CA 1998). For gold, see Benjamin Mountford and Stephen Tuffnell, A Global History of Gold Rushes (Oakland, CA, 2018) and Mai Ngai's work on the exclusion of Chinese miners from the goldfields, Mai Ngai, "Chinese Gold Miners and the 'Chinese Question' in Nineteenth-Century California and Victoria," The Journal of American History 101 (2015): 1082-1105.

6. Berger, "Introduction," 3.

7. Stefan Berger, "Mining history: sub-fields and agendas," in Making Sense of Mining History: Themes and Agendas, ed. Stefan Berger and Peter Alexander (London, 2019), 20.

8. Andrew Taylor, "So Many Cases but So Little Comparison: Problems of Comparing Mineworkers," in Stefan Berger, Andy Croll and Norman LePage, eds., Towards a Comparative History of Coalfield Societies (London, 2005): 12-28.

9. Berger, "Introduction," 4.

10. Berger, "Mining History," 2.

11. Miles and Phizacklea presented their thesis that racial divisions created "fractions" in the working class in Robert Miles and Annie Phizacklea, Labor and Racism (London, 1980).

12. David Roediger and Elizabeth Esch, The Production of Difference: Race and the Management of Labor in U.S. History (New York, 2014), 118-120.

13. Daniel E. Bender and Jana K. Lipman, eds., Making the Empire Work: Labor and United States Imperialism (New York, 2015); Julie Greene, The Canal Builders: Making America's Empire at the Panama Canal (New York, 2010); Jason M. Colby, The Business of Empire: United Fruit, Race, and U.S. Expansion in Central America (Ithaca, NY, 2011). On the Panama Canal, see also Michael Conniff, Black Labor on a White Canal: Panama, 1904-1981 (Pittsburgh, PA, 1985).

14. Roediger and Esch, Production of Difference, 115-121; John Higginson, "Privileging the machines: American engineers, indentured Chinese and white workers in South Africa's deep-level gold mines, 1902-1907," International Review of Social History 52 (2007): 1-34. 
15. Stuart Hall, The Fateful Triangle: Race, Ethnicity, Nation (Cambridge, Mass., 2017), 32.

16. Ibid., 47.

17. Stuart Hall, "Race, Articulation, and Societies Structured in Dominance," in Sociological Theories: Race and Colonialism (Paris, 1980), 341.

18. Eric Hobsbawm, The Age of Empire, 1875-1914 (London, 198), 63.

19. Sanjay Subrahmanyam, "Connected Histories: Notes towards a Reconfiguration of Early Modern Eurasia,” Modern Asian Studies 31 (1997): 761.

20. Limin Teh, "Labor Control and Mobility in Japanese-Controlled Fushun Coalmine (China), 1907 -1932," International Institute for Social History 60 (2015): 102.

21. J.L.H. Cailteux et al., "Genesis of sediment-hosted stratiform copper-cobalt deposits, central African Copperbelt," Journal of African Earth Sciences 42 (2005): 134-158.

22. Christopher Schmitz, “The Changing Structure of the Global Copper Market, 1870-1939," The Journal of European Economic History 2 (1997): 301.

23. RAA was a subsidiary of the South African mining conglomerate Anglo American and RST was majority owned by the American Metal Company.

24. Raymond Dumett, “Africa's Strategic Minerals during the Second World War," Journal of African History 26 (1985): 393.

25. Bruce Fetter, "L'union minière du Haut-Katanga, 1920-1940: a naissance d'une sous-culture totalitaire," Les cahiers du CEDAF 6 (1973): 1-40.

26. Minami manshū tetsudō kabushiki kaisha, Showa 13 nen hanbai tōkei.

27. Ramon H. Myers, "South Manchuria Railway Company," in Peter Duus, Ramon H. Myers and Mark R. Peattie, eds., The Japanese Informal Empire in China, 1895-1937 (Princeton, NJ, 1989), 126.

28. In some ways the division over skill reflected a racial division as work performed by Africans and Chinese was generally labelled unskilled-thus justifying lower pay-regardless of the tasks performed.

29. Duncan Money, “No matter how much or how little they've got, they can't settle down': A social history of Europeans on the Zambian Copperbelt, 1926-74" (DPhil. diss., Oxford University, 2016), Appendix II; Limin Teh, "Mining for Differences: Race, Chinese Labor, and Japanese Colonialism in Fushun Coalmine, 1907-1945” (Ph.D. diss., University of Chicago, 2014), Appendix 1.

30. Charles Perrings, Black Mineworkers in Central Africa: Industrial strategies and the evolution of an African proletariat in the Copperbelt 1911-41 (London, 1979), 12-13, 30.

31. UMHK also operated one underground mine, Prince Leopold Mine.

32. John Higginson, A Working Class in the Making: Belgian Colonial Labor Policy, Private Enterprise, and the African Mineworkers, 1907-1951 (Madison, WI, 1989), 87.

33. Union Minière du Haut Katanga, Le Katanga. Pays du Cuivre (Liège, 1930), 10.

34. Mantetsu Dainiji Jūnenshi, 108.

35. From 1941 a color bar restricting skilled work to white workers was imposed in Northern Rhodesia.

36. Dai kyukai kōjin soshitsu tōkei (1940).

37. David Northup, Beyond the Bend in the River: African Labor in Eastern Zaire, 1865-1940 (Athens, OH, 1988), 99.

38. Mwelwa Musambachime, "Escape from Tyranny: Flights Across the Rhodesia-Congo Boundary, 1900-1930," Transafrican Journal of History 18 (1989): 151.

39. Jane Parpart, Labor and Capital on the African Copperbelt (Philadelphia, PA, 1983), 166.

40. Rhodesian Anglo American, Mining developments in Northern Rhodesia (Johannesburg, 1929), 63.

41. Mantetsu dainiji jūnenshi, 140 .

42. Bujun tanko dokuhon, 49-70.

43. African Labour - Earnings per Shift, 1930-1950, 12.7.3A, Zambia Consolidated Copper Mines Archive, Ndola.

44. Statement Giving Details of Mining Basic Wages of Qualified Days Pay Employees, SEC1/1399, National Archives of Zambia, Lusaka. Total average wage earnings for white workers were thirty-four times higher than wage earnings for African workers in 1940. Robert Baldwin, Economic Development and Export Growth: A study of Northern Rhodesia, 1920-1960 (Cambridge, 1966), 90.

45. Higginson, Working Class in the Making, 179.

46. This is an annualized average from across the decade. Dacil Juif and Ewout Frankema, "From Coercion to Compensation: Institutional Responses to Labor Scarcity on the African Copperbelt," Journal of Institutional Economics 14 (2016): 14. 
47. Similar practices existed in mining camps in Chile. Thomas Klubock, Contested communities: Class, gender and politics in Chile's El Teniente Copper Mine, 1904-1951 (London, 1998), 266-267.

48. For a short period in the 1910s, African workers at UMHK recruited from British colonies were paid in pound sterling.

49. "The Currency Situation in Manchuria," 495.

50. South Manchuria Railway, Third Report on Progress in Manchuria, 1907-1932 (Dairen, 1933), 117.

51. "Native Viewpoint on Equal Pay for Equal Work," The Bulawayo Chronicle, December 2, 1945.

52. Sofie Boonen and Johan Lagae, "A City Constructed by 'des gens d'ailleurs'. Urban Development and Migration Policies in Colonial Lubumbashi, 1910-1930," Comparativ 25 (2015): 56-57.

53. Mantetsu Dainiji Jūnenshi, 157-158.

54. Manshū kenchiku kyōkai hakkō [Manchuria Building Cooperative], "Shinbujun no shigai keikaku to sono kenchiku," Manshū kenchiku kyōkai zasshi 14, 4 (1933): 22-23.

55. Ibid.

56. Isao Takano, Manshū rōmu kanri gairon (Shinkyō, 1939), 28.

57. Troops or armed police fired upon strikers in each of these disputes, killing and injuring large numbers of African mineworkers. Henry Meebelo, African Proletarians and Colonial Capitalism: The origins, growth, and struggles of the Zambian labour movement to 1964 (Lusaka, 1986), 68-83; Higginson, Working Class in the Making, 173-194.

58. Emer Sinéad O'Dwyer, Significant Soil: Settler Colonialism and Japan's Urban Empire in Manchuria (Cambridge, MA, 2015), 254, 259, 263, 268-269.

59. Ibid., 202-203.

60. Mantetsu dainiji jünenshi, 150.

61. O’Dwyer, Significant Soil, 218.

62. Ibid., $218-220$.

63. Duncan Money, "The World of European Labour on the Northern Rhodesian Copperbelt, 1940-1945," International Review of Social History 60 (2015): 225-255.

64. From a New Year's card designed by a Japanese mineworker in Fushun, cited in O'Dwyer, 284.

65. For more, see Prasenjit Duara, "Between Empire and Nation: Settler Colonialism in Manchukuo," in Caroline Elkins and Susan Pedersen, eds., Settler Colonialism in the Twentieth Century: Projects, Practices, and Legacies (London and New York, 2005), 59-78.

66. Perrings, Black Mineworkers, 51.

67. Money, "World of European Labour."

68. Ad Knotter, "Migration and Ethnicity in Coalfield History: Global Perspectives," International Review of Social History 60 (2015): 38-39.

69. Perrings, Black Mineworkers, 252.

70. Union Minière du Haut Katanga, Pays du Cuivre, 41; Robert Kuczynski, Demographic Survey of the British Colonial Empire Volume II (London, 1949), 422.

71. Perrings, Black Mineworkers, 54.

72. Parpart, Labor and Capital, 34-37.

73. Dai kyukai kōjin soshitsu tōkei (1940).

74. Heyin Yu, Fushun meikuang baogao (Nongshang bu kuangzheng siyinhang, 1926), 157-164.

75. Mantetsu Dainiji Jünenshi, 108, 137-140.

76. Bujun tanko dokuhon, 43-48.

77. Mantetsu dainiji jūnenshi, 202-203.

78. 1942 Bujun tanko tokei nenpo, 278-279.

79. Money, "World of European Labour," 242-243.

80. Frederick Cooper and Ann Laura Stoler, eds., "Between Metropole and Colony: Rethinking a Research Agenda," Tensions of Empire: Colonial Cultures in a Bourgeois World (Berkeley, CA, 1997), 10.

Cite this article: Money D, Teh L (2022). Race at Work: A Comparative History of Mining Labor and Empire on the Central African Copperbelt and the Fushun Coalfields, ca. 1907-1945. International Labor and Working-Class History 101, 100-117. https://doi.org/10.1017/S0147547921000132 